\title{
Bermuda Grass as a Potential Reservoir Host for Grapevine fanleaf virus
}

\author{
K. Izadpanah and M. Zaki-Aghl, Department of Plant Protection, College of Agriculture, Shiraz University, Shi- \\ raz, Iran; and Y. P. Zhang, S. D. Daubert, and A. Rowhani, Department of Plant Pathology, University of Califor- \\ nia, Davis 95616
}

\begin{abstract}
Izadpanah, K., Zaki-Aghl, M., Zhang, Y. P., Daubert, S. D., and Rowhani, A. 2003. Bermuda grass as a potential reservoir host for Grapevine fanleaf virus. Plant Dis. 87:1179-1182.

Grapevine fanleaf virus (GFLV) was detected in samples of Bermuda grass (BG) from Iran by reverse transcription-polymerase chain reaction (RT-PCR) using two different pairs of GFLVspecific primers, and also by enzyme-linked immunosorbent assay (ELISA) using antiserum specific for a North American isolate of the virus. RT-PCR detected GFLV in both fresh and dried BG tissues and in virus preparations purified from these plants. Cloning and sequencing of the RT-PCR products confirmed that the amplified sequences were sections of the GFLV coat protein gene. Similar results were obtained when random and oligo(dT) primers were used on viral RNA templates recovered from BG to synthesize cDNA for cloning and sequencing. The virus induced few or no symptoms in BG, but could nonetheless be transmitted from BG to Chenopodium quinoa by mechanical inoculation. Some isolates induced systemic chlorotic spots and leaf deformation; others remained symptomless in this plant. Both symptomatic and symptomless $C$. quinoa plants were found to be infected with GFLV, giving positive ELISA and RT-PCR tests. A North American isolate of GFLV was found to be mechanically transmissible to BG as indicated by positive RT-PCR results from root samples of inoculated plants. GFLVinfected BG was widely distributed in the Fars province of Iran.
\end{abstract}

Additional keywords: nepoviruses, virus epidemiology

Grapevine fanleaf virus (GFLV) is one of the oldest known viruses of grapevine and has been a major component of grapevine degeneration (11). It has probably existed in western Asian and Mediterranean countries since the early times of grape cultivation (19). The virus apparently originated from ancient Persia and spread to the west (19) en route to its current worldwide distribution. In Iran, grapes are currently cultivated on about 270,000 ha, producing 2.1 million tons annually. It is believed that transportation of vine stock, particularly of tolerant Vitis vinifera L. cultivars, has played a major role in longdistance spread of GFLV (4). While the virus has a wide experimental host range, Vitis spp. are regarded as its only natural hosts $(5,6,11)$ and are believed to be the main reservoir of GFLV. Recently, however, GFLV-like viruses were reported from Aristolochia clematitis L. and Lagenaria siceraria (Molina) Standl. in Hungary (7).

In a study of viruses of Bermuda grass (BG; Cynodon dactylon L.), we detected a virus which was copurified with Bermuda

Corresponding author: A. Rowhani
E-mail: akrowhani@ucdavis.edu

Accepted for publication 2 May 2003.

Publication no. D-2003-0714-03R

(C) 2003 The American Phytopathological Society grass etched-line virus (BELV). In this paper, we present serological and molecular evidence that the unknown virus was GFLV.

\section{MATERIALS AND METHODS}

Sources of Bermuda grass. In Davis, CA, apparently healthy BG plants were obtained from backyard gardens and planted in sterile soil mix in the greenhouse. In Shiraz and other districts of Fars Province, Iran, BG plants were collected from 34 different sites including street sides, fields, and vineyards. The Iranian BG samples either were symptomless or showed etching on the leaves attributed to BELV.

Inoculations. GFLV-infected leaves of Chenopodium quinoa (Willd.) and BG were used as sources of inoculum for mechanical transmission tests. The tissues were ground in 2 to $3 \mathrm{vol}$ of $0.06 \mathrm{M}$ sodium phosphate buffer, $\mathrm{pH}$. 8.0, and the extract was rubbed on Carborundumdusted leaves of either $\mathrm{BG}$ or $C$. quinoa maintained in the greenhouse. Resulting infections were verified by enzyme-linked immunosorbent assay (ELISA) and/or reverse transcription-polymerase chain reaction (RT-PCR).

Serological tests. A polyclonal antiserum prepared against a California isolate of GFLV was used throughout this study. ELISA, using $\mathrm{F}\left(\mathrm{ab}^{\prime}\right)_{2}$ fragments for coating the plate (17), was employed to detect GFLV serologically either in BG or $C$. quinoa samples. Test samples were ground in 5 to $10 \mathrm{vol}(\mathrm{wt} / \mathrm{vol})$ of $10 \mathrm{mM}$ phosphate (pH 7.4) specimen buffer ( $8 \mathrm{~g}$ of $\mathrm{NaCl}, 0.2$ $\mathrm{g}$ of $\mathrm{KH}_{2} \mathrm{PO}_{4}, 2.9 \mathrm{~g}$ of $\mathrm{Na}_{2} \mathrm{HPO}_{4} \cdot 12 \mathrm{H}_{2} \mathrm{O}$, $0.2 \mathrm{~g}$ of $\mathrm{KCl}, 20 \mathrm{~g}$ of polyvinylpyrrolidone $40,2 \mathrm{~g}$ of bovine serum albumin, and 0.5 $\mathrm{ml}$ of Tween 20 per liter).

RT-PCR. Single-tube RT-PCR (18) was used for detection of GFLV in BG and $C$. quinoa. Two pairs of GFLV-specific primers were used to amplify parts of the coat protein gene. Primer pairs included: GFLV V1: 5' ACC GGA TTG ACG TGG GTG AT $3^{\prime}$ and GFLV C1: 5' CCA AAG TTG GTT TCC CAA GA 3', which produced a PCR product size of $311 \mathrm{nt}$; and $\mathrm{CP} 433 \mathrm{~V}$ : 5' GAA CTG GCA AGC TGT CGT AGA AC $3^{\prime}$ and CP $912 \mathrm{C}$ : 5' GCT CAT GTC TCT CTG ACT TTG ACC 3', which produced a PCR product size of $480 \mathrm{nt}$. Leaf samples for RT-PCR reactions either were prepared as described previously (18) or total RNA was extracted using Qiagen's RNeasy Plant Mini Kit column (following the manufacturer's protocol; Qiagen Inc., Valencia, CA). Purified virus preparations were tested by adding aliquots to RT-PCR reactions.

Cloning and sequencing. Viral RNA was extracted from virus preparations purified from naturally infected BG by phenolchloroform extraction and ethanol precipitation. The Superscript cDNA synthesis and cloning kit (Gibco BRL, Carlsbad, CA) was used to synthesize cDNA on RNA templates using coat protein-specific primer pairs or random primers and oligo(dT). Double-stranded cDNA products were cloned and sequenced as described $(8,20)$. Alternatively, PCR products were ligated to the $\mathrm{pCR}^{\circledR} 2.1$ vector (Invitrogen, Carlsbad, CA) and cloned. The clones were sequenced at the sequencing facility of the University of California at Davis. The BG sequence was compared with that of an isolate of GFLV published previously (Accession no. X16907).

Virus purification. Purification of viruses from naturally infected BG plants was carried out by differential and densitygradient centrifugation as described earlier for BELV (12).

\section{RESULTS}

Detection of GFLV in BG. GFLV was detected by RT-PCR in 14 out of 34 BG samples collected from different areas of Fars Province, Iran. Most of these infected BG samples were collected adjacent to vineyards with histories of GFLV infec- 
tion. Both leaves, and rhizomes and roots (combined) from BG plants tested positive, as either fresh or dry tissue (Fig. 1). The same results were obtained when purified preparations of BELV (from naturally infected BG) were used as templates for RT-PCR. GFLV was detected both in BELV-infected BG as well as in asymptomatic samples (asymptomatic BG plants tested in different experiments were free from BELV). GFLV was also detected by ELISA in virus-infected samples of BG. Certain samples, however, required purification and concentration of the virus to permit detection, especially when BG plants were coinfected with BELV.
Although many samples were positive for GFLV by both ELISA and RT-PCR, the latter was more sensitive. For example, in one experiment in which 13 BG plants were tested, 6 were positive for GFLV by ELISA, while 11 were positive by RTPCR.

Transmission of GFLV to and from BG. In a few plants, mechanical inoculation of $C$. quinoa with GFLV-positive BG extracts resulted in development of systemic vein clearing, chlorotic spotting, and leaf distortion (Fig. 2); these plants were positive for GFLV by both ELISA and RTPCR. However, most inoculated C. quinoa plants that were positive in these tests remained symptomless or showed only leaf

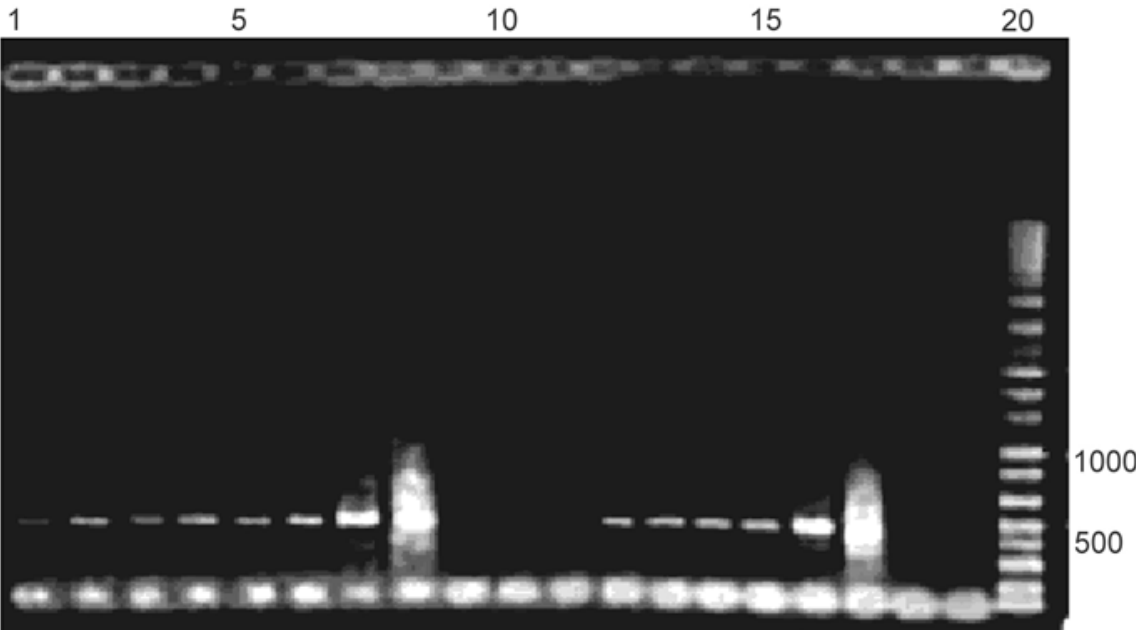

Fig. 1. Electrophoresis pattern of reverse transcription-polymerase chain reaction (RT-PCR) products with Grapevine fanleaf virus (GFLV)-specific primer pair 433v/912c and dried Bermuda grass samples of roots (lanes 1 to 3,12, and 13) and leaves (lanes 4 to 6,14, and 15) from Iran, purified preparation of Bermuda grass samples from Iran (lanes 8 and 17), and GFLV-infected Chenopodium quinoa (lanes 7 and 16). Lane 20 is the DNA marker.

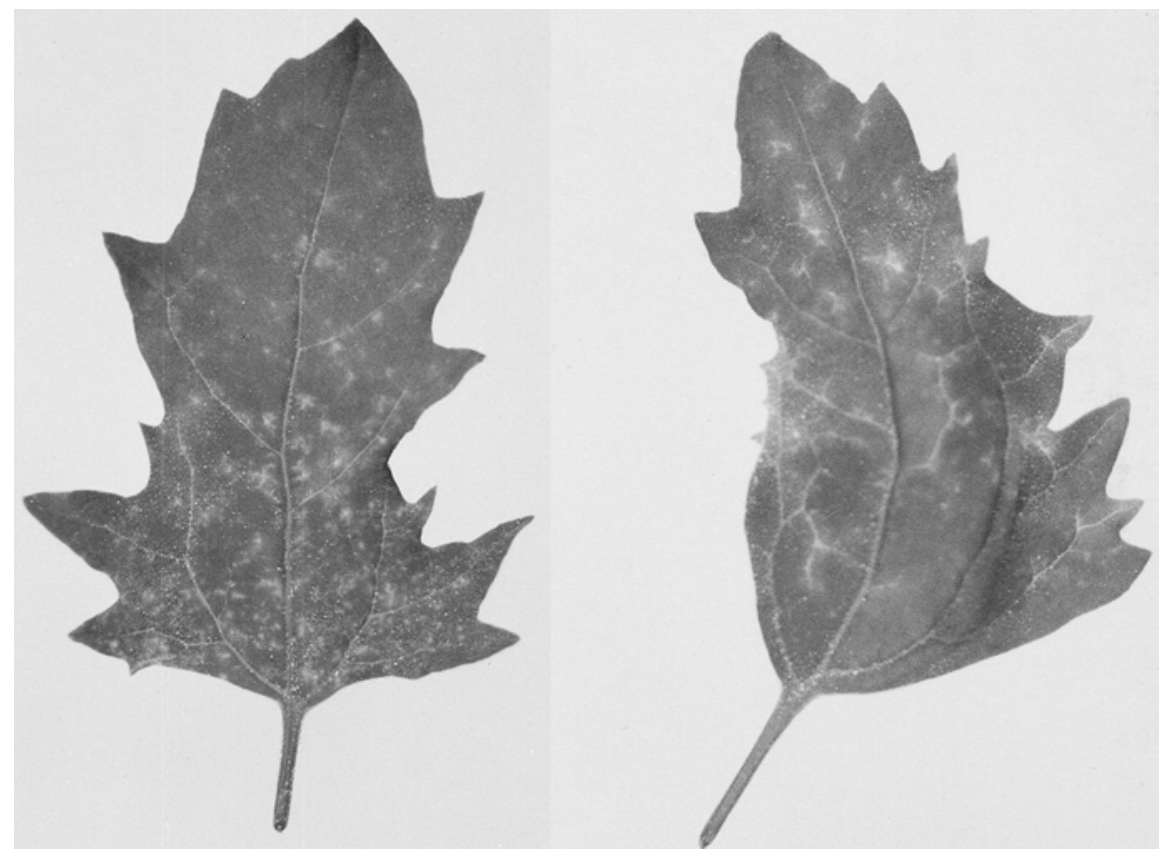

Fig. 2. Systemic vein clearing, chlorotic spotting, and leaf distortion in Chenopodium quinoa 2 weeks after inoculation with Grapevine fanleaf virus (GFLV)-positive Bermuda grass extract. distortion. For example, in two experiments, 29 and $43 C$. quinoa plants were inoculated with GFLV-infected BG homogenate: only five and three plants, respectively, produced symptoms, but when these plants were tested by ELISA, 17 and 14 plants, respectively, were positive for GFLV. Rubbing of purified virus preparations recovered from BG also resulted in GFLV infection in C. quinoa.

In another experiment, 20 healthy BG plants were mechanically inoculated with a Davis isolate of GFLV from C. quinoa. The results were assessed by RT-PCR. No virus could be detected in inoculated BG leaves 2 weeks after inoculation. However, most plants were shown to be infected when their fine roots and underground stems were tested 5 weeks after inoculation. Noninoculated control plants tested negative.

Cloning and sequencing. Sequencing confirmed that PCR products obtained using GFLV-specific primers on BG extracts were indeed sections of a GFLVrelated coat protein gene. Their nucleotide sequences showed $89 \%$ identity with the homologous section of the published sequence of an isolate of GFLV as seen in the example shown in Figure 3. Many of the nucleotide differences either were silent or led to conservative amino acid substitutions, such that inferred amino acid sequences were $96 \%$ similar.

In another experiment, viral RNA from a virus preparation from naturally BELVinfected BG plants was used for synthesis of cDNA using random and oligo(dT) primers (8). Eighteen resultant clones were identified as BELV sequences, but two were found to be homologous with the GFLV coat protein gene.

\section{DISCUSSION}

Regular detection of GFLV in Bermuda grass by RT-PCR using two GFLV-specific primer pairs and identification of the sequence of the amplified products as regions of the GFLV coat protein gene demonstrate the presence of a GFLV-like entity in BG in Iran. The RT-PCR-based identification was confirmed both (i) by the discovery of regions of GFLV CP sequence during sequencing of cDNAs synthesized from virions prepared from BG using nonspecific primers, and (ii) by the serological reactivity of these virus preparations against GFLV-specific antiserum. Transmission experiments from BG to $C$. quinoa, producing an infection with characteristic GFLV serological reactivity and, in some cases, GFLV symptoms, confirmed that this entity is indeed a GFLV isolate. RTPCR and ELISA results show that this virus has a lower concentration in BG than in $C$. quinoa. Its milder symptoms in $C$. quinoa and its sequence variance $(89 \% \mathrm{CP}$ sequence identity from the published sequence) showed that it is a distinct strain of GFLV. Infection of BG with a grapevine 
isolate of GFLV further confirmed that BG is a host for the virus.

Bermuda grass is an ubiquitous weed, widespread in Iran and many other countries. As a perennial plant, it may be a source for the perpetuation of several plant viruses. BELV, Cynodon chlorotic streak virus, and Barley yellow dwarf virus are among those reported from BG $(3,9,10,12)$. Recently, we identified two previously unreported potyviruses infecting this plant in various locations in Iran (unpublished). All these viruses, however, are adapted to and confined in gramineous species. The discovery of a natural infection of BG by GFLV is surprising, as all previously known natural and experimental hosts of this virus are dicotyledonous species.

Despite the wide experimental host range of GFLV, grapevine has been regarded as the major field host in which the virus survives and the source from which the virus spreads $(6,11)$. It is assumed that GFLV and several other viruses of grape have spread vegetatively throughout the world from their origin in the Middle East by transport of vines or their vegetative propagating material $(4,11)$. The present finding of a natural infection of GFLV in BG gives a new dimension to the virus epidemiology. For example, extension of the viral host range to include a common weedy species raises the possibility that, under some circumstances, fanleaf infection in grapevine may originate from nonwoody reservoirs (7). Vector transmission of such infections has not been documented and would require either (i) the participation of a broad host range nematode, such as a member of the Xiphinema americanum complex $(1,16$; represented in Iran by $X$. pachtaicum, 13), or (ii) participation of $X$. index (also in Iran, 13) or $X$. italiae (2) forms having broader host ranges than those now documented for these species.

One or more of a broad spectrum of longidorid nematodes can be found in every grape-growing region in the world, and with the exception of vineyard strains of $X$. index, they all have broad host ranges $(1,15)$. GFLV has an adaptable genome
(14) which could allow for the evolution of viral pathogenesis in grape arising from (initially cryptic) herbaceous strains of the virus. The possible existence of weed strains of GFLV in proximity to vineyards suggests that management to control fanleaf disease should include the control of potential weedy reservoir sources of virus. It also points up the need for more definitive studies of both the host range and variability of the virus, as well as of the host ranges and intraspecific variability of Xiphinema species, and of vector capabilities of the various longidorid nematodes found in vineyard soils.

\section{ACKNOWLEDGMENTS}

We thank H. Ferris, Department of Nematology, U.C. Davis, for his advice on this paper.

\section{LITERATURE CITED}

1. Brown, D., Halbrendt, J., Robbins, R., and Vrain, T. 1993. Transmission of Nepoviruses by Xiphinema americanum-group nematodes. J. Nematol. 25:349-354.

2. Cohn, E., Tanne, E., and Nitzany, F. E. 1970. Xiphinema italiae, a new vector of grapevine fanleaf virus. Phytopathology 60:181-182.

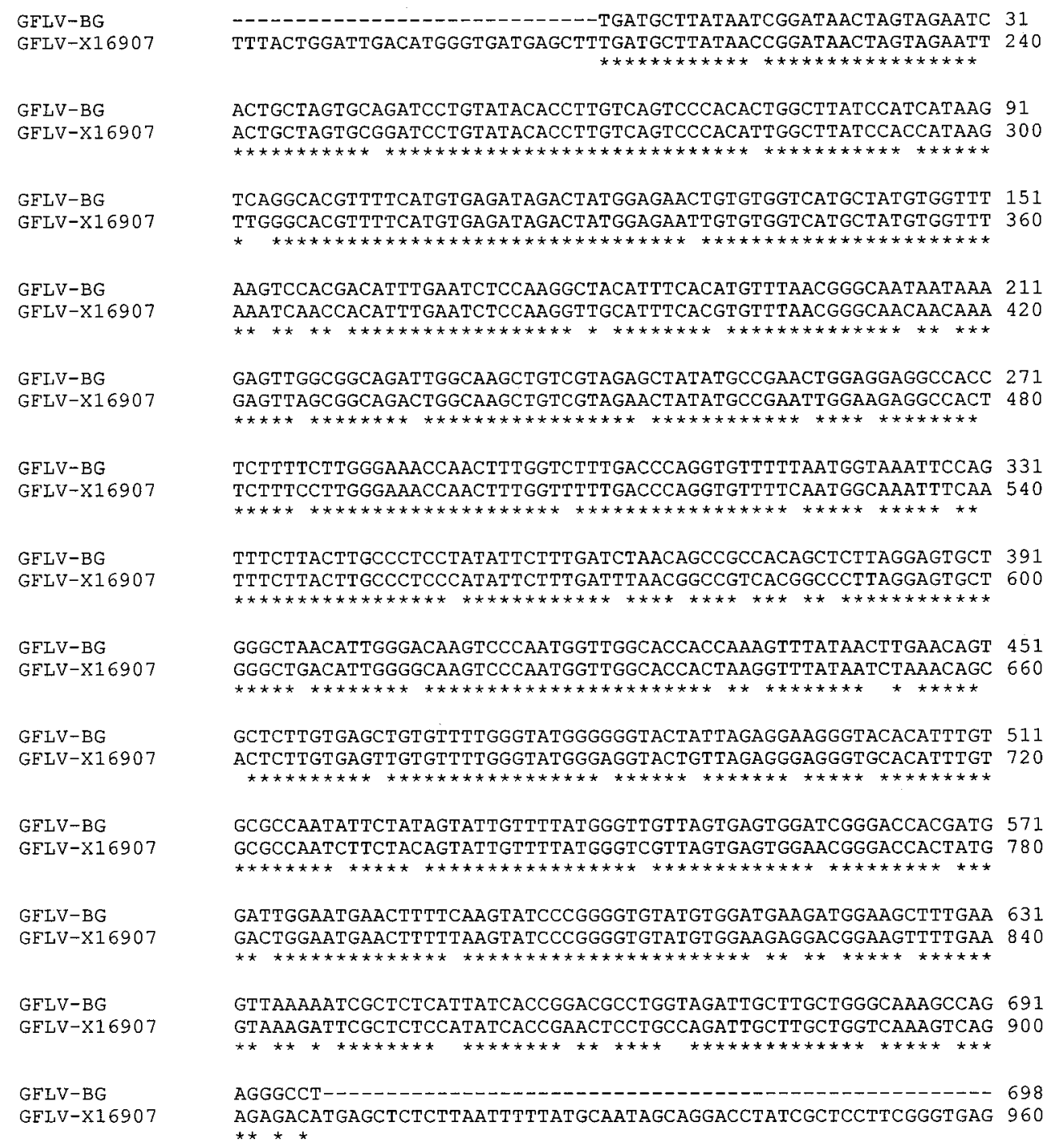

Fig. 3. Alignment of a 698-bp section of the nucleotide sequence of Grapevine fanleaf virus (GFLV)-BG, a Bermuda grass isolate, with nucleotides 210 to 907 of the coat protein gene of GFLV, a grapevine isolate (Accession no. P18474). 
3. D'Arcy, C. J. 1995. Symptomatology and host range of barley yellow dwarf. Pages 9-28 in: Barley Yellow Dwarf, 40 Years of Progress. C. J. D'Arcy and P. A. Burnett, eds. American Phytopathological Society, St. Paul, MN.

4. Hewitt, W. 1970. Virus and virus-like diseases of the grapevine. Pages 9-28 in: Virus Diseases of Small Fruits and Grapevine. N. W. Frazier, ed. University of California, Berkeley.

5. Hewitt, W. B., Martelli, G., Dias, H. F., and Taylor, R. H. 1970. Grapevine fanleaf virus. CMI/AAB Descriptions of Plant Viruses. No. 28.

6. Hewitt, W. B., Raski, D. J., and Goheen, A. C. 1958. Nematode vector of soil-borne fanleaf virus of grapevines. Phytopathology 48:586595.

7. Horvath, J., Tobias, I., and Hunyadi, K. 1994. New natural herbaceous hosts of grapevine fanleaf nepovirus. Kerteszeti Tudomany (Hortic. Sci.) 26:31-32

8. Izadpanah, K., Zhang, Y. P., Daubert, S., Masumi, M., and Rowhani, A. 2002. Sequence of the coat protein gene of Bermuda grass etched-line virus and of the adjacent marafibox motif. Virus Genes 24:131-134.

9. Lockhart, B. E. L., Khaless, N., El Maataoui,
M., and Lastra, R. 1985. Cynodon chlorotic streak virus, a previously undescribed plant rhabdovirus infecting Bermuda grass and maize in the Mediterranean area. Phytopathology 75:1094-1098.

10. Lockhart, B. E. L., Khaless, N., Lennon, A. M., and El Maataoui, M. 1985. Properties of Bermuda grass etched-line virus, a new leafhopper-transmitted virus related to maize rayado fino and oat blue dwarf viruses. Phytopathology 75:1258-1262.

11. Martelli, G. P., and Savino, V. 1988. Fanleaf degeneration. Pages 48-49 in: Compendium of Grape Diseases. R. C. Pearson and A. C. Goheen, eds. American Phytopathological Society, St. Paul, MN.

12. Masumi, M., and Izadpanah, K. 1996. Properties of the Iranian isolate of Bermuda grass etched-line virus. J. Phytopathol. 44:231-234.

13. Mojtahedi, H., Sturham, D., Akhiani, A., and Barooti, S. 1980. Xiphinema species in Iranian vineyards. Nematol. Mediterr. 8:165174.

14. Naraghi-Arani, P., Daubert, S., and Rowhani, A. 2001. Quasispecies nature of the genome of Grapevine fanleaf virus. J. Gen. Virol. 82:1791-1795.
15. Raski, D. J. 1988. Dagger and Needle Nematodes. Pages 56-57 in: Compendium of Grape Diseases. R. C. Pearson and A. C. Goheen, eds. American Phytopathological Society, St. Paul, MN.

16. Robbins, R., and Brown, D. 1991. Comments on the taxonomy, occurrence and distribution of Longidoridae (Nematoda) in North America. Nematologica 37:395-419.

17. Rowhani, A. 1992. Use of $\mathrm{F}\left(\mathrm{ab}^{\prime}\right)_{2}$ antibody fragment in ELISA for detection of grapevine viruses. Am. J. Enol. Vitic. 43:38-40.

18. Rowhani, A., Biardi, L., Johnson, R., Saldarelli, P., Zhang, Y. P., Chin, J., and Green, M. 2000. Simplified sample preparation method and one-tube RT-PCR for grapevine viruses. Page 148 in: Proc. Meeting ICVG, 13th, Adelaide, Australia.

19. Vuittenz, A. 1970. Fanleaf of grapevine. Pages 217-228 in: Virus Diseases of Smal Fruits and Grapevine. N. W. Frazier, ed. University of California, Berkeley.

20. Zhang, Y. P., and Rowhani, A. 2000. A strategy for rapid cDNA cloning from doublestranded RNA templates isolated from plants infected with RNA viruses by using Taq DNA polymerase. J. Virol. Methods 84:59-63. 